Beata JAGIELA ${ }^{1}$

Marek GOSZTYŁA ${ }^{2}$

\title{
KONCEPCJE RESTAURACJI KLASZTORU OO. BERNARDYNÓW W RZESZOWIE WEDŁUG PROJEKTÓW ZYGMUNTA HENDLA
}

\begin{abstract}
Celem niniejszego opracowania jest próba analizy koncepcji restauracji zespołu OO. Bernardynów w Rzeszowie autorstwa krakowskiego architekta - Zygmunta Hendla. Architekt o znanym nazwisku i dorobku mógł stworzyć swoje koncepcje projektowe na obiekcie o cennych nawarstwieniach kulturowych, przy którym zatrudniani byli mistrzowie o najwyższym autorytecie. Pogłębiona analiza konceptu konserwatorskiego z I dekady XX wieku, przeprowadzona zostanie w oparciu o dokumentację projektową pochodzącą ze zbiorów Muzeum Narodowego w Krakowie. Projekty, których autorem jest jeden $\mathrm{z}$ wybitniejszych architektów i konserwatorów przełomu XIX i XX wieku, pozwalają przybliżyć przyjmowane metody postępowania konserwatorskiego w omawianym okresie. Projekty te, są na tyle cenne, że mogą dawać nowy pogląd na zachodzące zmiany w rozwoju konserwatorstwa. Pozwoli to w sposób znaczny pogłębić wiedzę tak w zakresie historii omawianego zabytku, jak i historii konserwacji zabytków na ziemiach Galicji w okresie autonomii. Architekt krakowski był autorem projektów oraz nadzorował prace konserwatorskie prowadzone w klasztorze w latach 1896-1906. Stworzył koncepcję nadbudowy obiektu, wprowadził propozycję opracowania arkadowego w formie wykształconych boni i klińców elewacji na parterze od strony dziedzińca klasztornego. Opracował projekt rozrzeźbienia elewacji poprzez zwieńczenie ryzalitu trójkątnym przyczółkiem oraz plastycznego podkreślenia narożnych linii pionowych projektując pilastry o trzonach boniowanych. Na przestrzeni lat 2004-2006 w klasztorze prowadzono prace osuszania murów fundamentowych, prace budowlano konserwatorskie murów zewnętrznych i wewnętrznych klasztoru. W roku 2009 zaakceptowano projekty rozbudowy i adaptacji poddasza klasztornego na funkcje mieszkalne oraz założenia ogrodowego od strony północnej. Prace wykonane na początku XXI wieku w swojej ogólnej koncepcji stanowią powrót do niezrealizowanych projektów Z. Hendla. Współczesna realizacja zachowując formę dachu skupiła się na poszerzeniu programu funkcjonalnego wnętrza.
\end{abstract}

Słowa kluczowe: zabytek architektury, kościół, klasztor, architekt, konserwacja zabytków, autonomia galicyjska

\footnotetext{
${ }^{1}$ Autor do korespondencji: Beata Jagieła, starszy wykładowca w Państwowej Wyższej Szkole Techniczno - Ekonomicznej w Jarosławiu, adres zamieszkania: ul. Polna 10/2, 37-500 Jarosław, tel. 798400009, beata.jagiela@op.pl

${ }^{2}$ Marek Gosztyła, kierownik Katedry Konserwacji Zabytków, Politechnika Rzeszowska, tel. 178651939, gosztyla@prz.edu.pl
} 


\section{Wstęp}

Na temat Bazyliki OO. Bernardynów w Rzeszowie napisano już wiele. Jest tak dlatego, że świątynia ta, będąca sanktuarium Matki Bożej Rzeszowskiej, należy do najznamienitszych zabytków miasta nad Wisłokiem, a jej nobliwa sylwetka stanowi jeden $\mathrm{z}$ najpiękniejszych i zarazem najbardziej charakterystycznych elementów w jego panoramie. Bodaj najnowszą publikacją opisującą zarówno dzieje, jak i architekturę zespołu klasztorno - kościelnego jest opracowanie o charakterze przewodnika autorstwa E. Kurowskiej oraz ojca W.P. Tokarskiego - proboszcza oraz kustosza Sanktuarium [7].

Celem autorów niniejszego artykułu nie może być więc powtarzanie treści, które się pojawiają we wspomnianym opracowaniu, a także publikacjach wcześniejszych, ale uzupełnienie ich o nowe, nieznane fakty do tej pory nie będące przedmiotem oddzielnego studium. Gros z nich dotyczy modernizacji jaką przeprowadzono w świątyni na przełomie XIX i XX stulecia, pod okiem znanego architekta, a zarazem wytrawnego konserwatora zabytków - Zygmunta Hendla.

\section{Rys historyczny zespołu OO. Bernardynów w Rzeszowie}

Opisywany zespół klasztorny w wraz z kościołem jest dobitnym dowodem na to, że przejście od stylu manierystycznego do wczesnobarokowego nie dokonało się nagle. Polegało ono na stopniowym wypieraniu jednych elementów przez drugie. W przypadku dzieł architektury, zważywszy na rozciągnięcie w czasie ich powstawania, widać to najwyraźniej.

Zespół klasztorny OO. Bernardynów, o którym mowa, wzniesiono w I połowie XVII w. w miejscu dużo starszej budowli sakralnej usytuowanej w tym miejscu - drewnianego kościółka p.w. Wniebowzięcia panny Marii [10, s. 45]. Jego powstanie było odpowiedzią na cudowne objawienie się w tym miejscu Matki Bożej Jakubowi Ado, które miało miejsce dnia 15 sierpnia 1513 roku. Obecny kościół i klasztor powstał dzięki ówczesnemu właścicielowi miasta M.S. Ligęzie, z zamysłem pomieszczenia mauzoleum rodowego. Sam fundator, ubrany w habit zakonny znalazł miejsce swego spoczynku pod progiem świątyni [3, s. 23-24].

Kościół będący dziełem budowniczych z Lipska powstał na przestrzeni lat 1624-1629. Ligęza przekazał obiekt Bernardynom w roku ukończenia prac. W I poł. XVIII stulecia (1735-1739) wykonano w obiekcie sakralnym nową polichromię, której fundatorem był Jerzy I. Lubomirski. Do kościoła wstawiono wówczas nowe nastawy ołtarzowe w kaplicach Pana Jezusa i Panny Marii oraz położono nową posadzkę.

Około 1832 roku pojawiły się w kościele nowe ołtarze: św. Antoniego, św. Franciszka i św. Jana z Dukli [7, s. 33]. 
Kościół został ponownie poddany renowacji w latach 1898-1909 pod kierunkiem Z. Hendla. Od tego czasu był parokrotnie restaurowany wliczając w to czasy współczesne, kiedy to odrestaurowano m.in. elewację świątyni.

Opis świątyni (zarówno jej architektury jak i wystroju) zawarty został w akcie donacyjnym Ligęzy. Według tego zapisu w kościół jest budowlą na planie krzyża łacińskiego z dwiema bocznymi kaplicami. W podziemiach małego chóru zakonnego usytuowanego $\mathrm{w}$ obrębie wschodniej części prezbiterium istniała niegdyś dodatkowo kolejna, trzecia kaplica - św. Krzyża [7, s. 32; 2, s. 199-202].

Kościół jest budowlą orientowaną, murowaną z cegły, dziełem o dużych walorach artystycznych, posiadającym późnorenesansowy charakter wzbogacony elementami baroku. Korpus główny świątyni jest jednonawowy, prezbiterium zamknięte półkolistą apsydą. W sylwecie budowli dominuje okazała wieża na planie kwadratu, dostawiona do jej bryły od strony zachodniej. Na skrzyżowaniu naw umieszczono kopułę, którą wieńczy pokaźna latarnia. Kaplice transeptu przesklepiono sklepieniami krzyżowymi, nawę zaś kolebką. Prostota bryły architektonicznej, pełne harmonii proporcje, ascetyczna dekoracja ograniczona do artykulacji otworów okiennych - to cechy należące do renesansowej puli środków formalnych $\mathrm{w}$ architekturze. Wspomniane okna, urozmaicające monotonię elewacji, zakomponowano w dwóch rzędach: w górnym okrągłe w lunetach, w dolnym zaś zamknięte łukiem półokrągłym. Rozwiązanie to dubluje układ otworów okiennych dzwonnicy.

Elementem świadczącym o rysie barkowym bryły budowli jest umieszczenie na skrzyżowaniu naw kopuły zwieńczonej latarnią.

Przy prezbiterium znajduje się zakrystia i oddzielne pomieszczenie skarbczyka. Ramiona transeptu przeznaczono na kaplice: od strony południowej znajdujemy kaplicę Matki Boskiej Rzeszowskiej, od strony północnej zaś kaplicę Pana Jezusa.

Wystrój kościoła posiada we większości przypadków pierwotny XVIIwieczny charakter, uzupełniony przez późniejsze elementy pochodzące z XVIII i XIX wieku. Powyższy, dość lapidarny w swej formule opis, udowadnia to, jak złożoną kwestią jest sztywna klasyfikacja stylowa konkretnego zabytku. „Niejednokrotnie bowiem bywa tak, że kolejne style architektoniczne nawarstwiają się tworząc w określonym obiekcie ciekawy mariaż stylistyczny. Nie jest też możliwe oddzielenie na zasadzie cięcia nożem wykwitów poszczególnych epok stylowych, gdyż ich przechodzenie jedna w drugą nie odbywało się nagle lecz na przestrzeni lat.”[3, s. 26]

\section{Projekty Zygmunta Hendla}

W latach 1898-1906 pod kierunkiem Zygmunta Hendla świątynia została gruntownie odnowiona. Projekty tej restauracji, które udało się odnaleźć w zbiorach Muzeum Narodowego w Krakowie, można podzielić na dwie zasadnicze kategorie: te dotyczące przekształceń (niezrealizowanych zresztą) 
bryły klasztoru oraz projekty wyposażenia kościoła. W pierwszej grupie znajdują się niniejsze projekty:

- Widok części Elewacji - Fragment I i II piętra, 1900 rok, ${ }^{3}$

- Fasada frontowa - Budynek o trzech kondygnacjach (parter, pierwsze i drugie piętro, podpiwniczony, ${ }^{4}$

- Fragment elewacji, 1900 rok. ${ }^{5}$ Fragment fasady o trzech kondygnacjach podpiwniczonych, 1900 rok, ${ }^{6}$

- Gzyms fasady frontowej, 1900 rok, ${ }^{7}$

- Plan odnowienia, 1900 rok, ${ }^{8}$

- Fragment fasady budynku od strony dziedzińca. ${ }^{9}$

Drugą grupę obejmują zaś projekty wymienione poniżej:

- Krypta grobowa - Ołtarz z marmuru, 1900 rok, ${ }^{10}$

- Projekt oszklenia okna witrażem, 1900 rok, ${ }^{11}$

- Projekt oszklenia okna witrażem, 1900 rok, ${ }^{12}$

- Projekt ażurowej bramki wykonanej z metalu, do balustrady oddzielającej prezbiterium od nawy, 1900 rok, ${ }^{13}$

- Fragment części Ołtarza Głównego - Projekt przebudowy, 1900 rok, ${ }^{14}$

- Wyposażenie wnętrza, stalle - 2 rys. Ujęcie frontalne stall, widok boczny, 1900. Projekt cyborium - 2 rys.: "Widok z frontu"; "Widok z boku", 1900 rok, ${ }^{15}$

- Konfesjonał - 3 rys.: Widok z boku; Widok frontalny; Plan, 1900 rok, ${ }^{16}$

- Balustrada w prezbiterium - 3 rys.: Profil dolnej części słupa; Górna płyta balustrady; Profil, 1900 rok, ${ }^{17}$

- 4 rys. Plan kościoła; Widok frontalny połowy balustrady wraz z bramką; Widok frontalny części stall; Widok boczny konfesjonału, 1900 rok. $^{18}$

- Posadzka, 1900 rok, ${ }^{19}$

- Przekształcenie tabernakulum - Projekt, 1900 rok, ${ }^{20}$

${ }^{3}$ Zbiory Muzeum Narodowego w Krakowie, Dział III, nr inw. MNK III-PL-815.

${ }^{4}$ Tamże, nr inw. MNK III-PL-816.

${ }^{5}$ Tamże, nr inw. MNK III-PL-817.

${ }^{6}$ Tamże, nr inw. MNK III-PL-820.

${ }^{7}$ Tamże, nr inw. MNK III-PL-825.

${ }^{8}$ Tamże, nr inw. MNK III-PL-832.

${ }^{9}$ Tamże, nr inw. MNK III-PL-852.

${ }^{10}$ Tamże, nr inw. MNK III-PL-814.

${ }^{11}$ Tamże, nr inw. MNK III-PL-818.

${ }^{12}$ Tamże, nr inw. MNK III-PL-819.

${ }^{13}$ Tamże, nr inw. MNK III-PL-821.

${ }^{14}$ Tamże, nr inw. MNK III-PL-823.

${ }^{15}$ Tamże, nr inw. MNK III-PL-826.

${ }^{16}$ Tamże, nr inw. MNK III-PL-827.

${ }^{17}$ Tamże, nr inw. MNK III-PL-829.

${ }^{18}$ Tamże, nr inw. MNK III-PL-830.

${ }^{19}$ Tamże, nr inw. MNK III-PL-831. 
- Projekt przebudowy - rysunek roboczy - Ołtarz główny (sic!) - Widok i przekroje fragmentów, 1900 rok, ${ }^{21}$

- Projekt mensy przed wielkim ołtarzem:2 rys.: Widok główny; Widok boczny, 1900 rok $^{22}$

- Projekt mensy przed wielkim ołtarzem - 3 rys.: Przekrój; Widok główny; Widok boczny, 1900 rok, ${ }^{23}$

- Plan prezbiterium balustrady przed głównym ołtarzem, 1900 rok, ${ }^{24}$

- Konfesjonat - 2 rys.: Widok frontalny; Ujęcie boczne, 1900 rok, ${ }^{25}$

- Przekształcenie tabernakulum ołtarza - Ujęcie frontalne, 1900 rok. $^{26}$

Projekty te wyszczególnione zostały w porządku kolejności sygnatur. Autorzy omówią je szczegółowo w tematycznych artykułach.

Krakowskiemu architektowi zawdzięczamy projekty dotyczące rozbudowy i przekształcenia elewacji budynku klasztornego OO. Bernardynów w Rzeszowie. Budynek klasztorny ,na podmurowaniu” powstał równolegle z kościołem bernardyńskim. Wiemy o nim tyle, że miał duże sklepienie piwnic, na parterze mieścił refektarz, kuchnie oraz izby w liczbie sztuk pięciu; na piętrze zaś trzynaście cel oraz obszerną salę. Był to obiekt drewniany do którego przynależała zabudowa o charakterze gospodarczym, tzw. „domek dla gościa” oraz ogród. Już na początku następnego stulecia dzięki fundacji najprawdopodobniej Hieronima Augustyna Lubomirskiego został zastąpiony nowym, murowanym budynkiem wzniesionym na przestrzeni lat 1702-1707 pod kierownictwem Piotra Belottiego, który pełnił na dworze H. A. i J. I. Lubomirskich funkcję nadwornego architekta. ${ }^{27}$ Autorem projektu budynku klasztornego był wybitny architekt Tylman z Gameren zamieszkujący wówczas w Warszawie. Jego częste bytności w grodzie nad Wisłokiem były spowodowane nadzorem prac prowadzonych wg jego projektu przy kościele pijarów oraz (a może - przede wszystkim) na zamku w Rzeszowie. [13, zał. 1]

Klasztor wg projektu Tylmana z Gameren przetrwał do chwili obecnej w prawie niezmienionej postaci (nie licząc adaptacji poddasza przeprowadzonej w I dekadzie XXI wieku). Jest to dwukondygnacyjny obiekt na rzucie czworoboku, posiadający kwadratowy dziedziniec. Przylega do kościoła od strony północno- zachodniej. W latach $40 . \mathrm{XX}$ wieku rozebrano mur otaczający przyklasztorny ogród, który przylegał do zachodniego oraz południowego skrzydła klasztoru.

Zespół klasztorny przeszedł dość gruntowną restaurację w latach 18961906 pod nadzorem Z. Hendla - jak się okazuje jednak nie wybrano wówczas jego dość rewolucyjnych projektów, zasadniczo ingerujących w bryłę obiektu.

\footnotetext{
${ }^{20}$ Tamże, nr inw. MNK III-PL-835.

${ }^{21}$ Tamże, nr inw. MNK III-PL-840.

${ }^{22}$ Tamże, nr inw. MNK III-PL-848.

${ }^{23}$ Tamże, nr inw. MNK III-PL-849.

${ }^{24}$ Tamże, nr inw. MNK III-PL-851.

${ }^{25}$ Tamże, nr inw. MNK III-PL-2066.

${ }^{26}$ Tamże, nr inw. MNK III-PL-2087.

${ }^{27}$ Warto zaznaczyć, ze przeszła ona w schedzie na jego syna - Jana Chrzciciela Belottiego.
} 
Hendel zdecydował się urozmaicić elewację frontową klasztoru poprzez wprowadzenie na osi ryzalitu trójkątnego naczółka oraz wzmocnić linie pionowe poprzez wprowadzenie boniowania na narożach ryzalitu i być może także rozdzielające kolejne osie elewacji (rys. 1). Jak widać na jednym z nich, architekt miał zamiar podwyższyć budynek klasztoru o dodatkową kondygnację. Warto też zwrócić uwagę na fakt, że otwory okienne pierwszej kondygnacji dziedzińca miały zostać według tej śmiałej koncepcji ujęte arkadowym boniowaniem, co przywodzi na myśl rozwiązanie zastosowane przez $\mathrm{H}$. Skowrona w projektach dziedzińca nowopowstałego zamku rzeszowskiego, obecne także na wcześniejszych projektach Hendla dotyczących adaptacji zamku w Rzeszowie dla potrzeb więziennictwa, które mogły być w tym przypadku pierwowzorem ${ }^{28}$ (rys. 2).

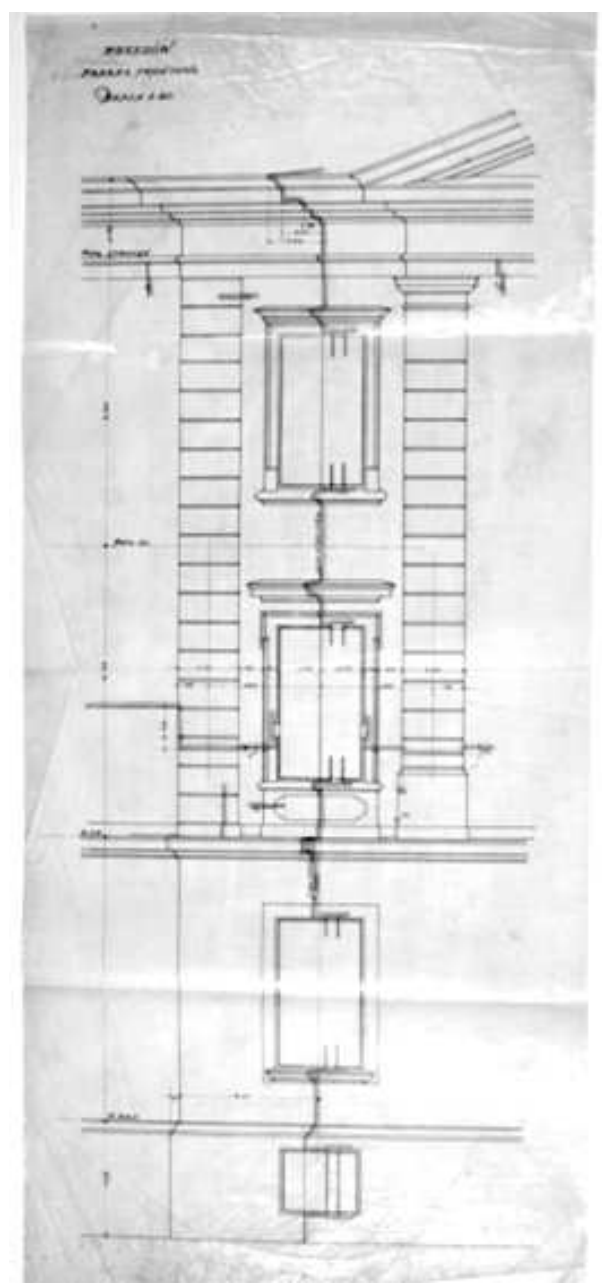

Rys. 1. Fasada frontowa, Muzeum Narodowe w Krakowie ${ }^{29}$

Fig. 1. The front facade, National Museum in Krakow

${ }^{28}$ Zob. B. Jagieła, Zygmunt Hendel i jego niezrealizowane projekty adaptacji zamku Lubomirskich w Rzeszowie dla potrzeb więziennictwa, [w:] Zeszyty naukowe Politechniki Rzeszowskiej „Budownictwo i inżynieria środowiska”, z. 59, nr 2/2012/II, t. I, s. 349-360.

${ }^{29}$ Zygmunt Hendel, Rzeszów - Kościół przy klasztorze OO. Bernardynów - Fasada frontowa Budynek o trzech kondygnacjach (parter, pierwsze i drugie piętro, podpiwniczony), 95 x $41.6 \mathrm{~cm}$, tusz, płótno, Zbiory Muzeum Narodowego w Krakowie, Dział III, nr inw. MNK III-PL-816. 


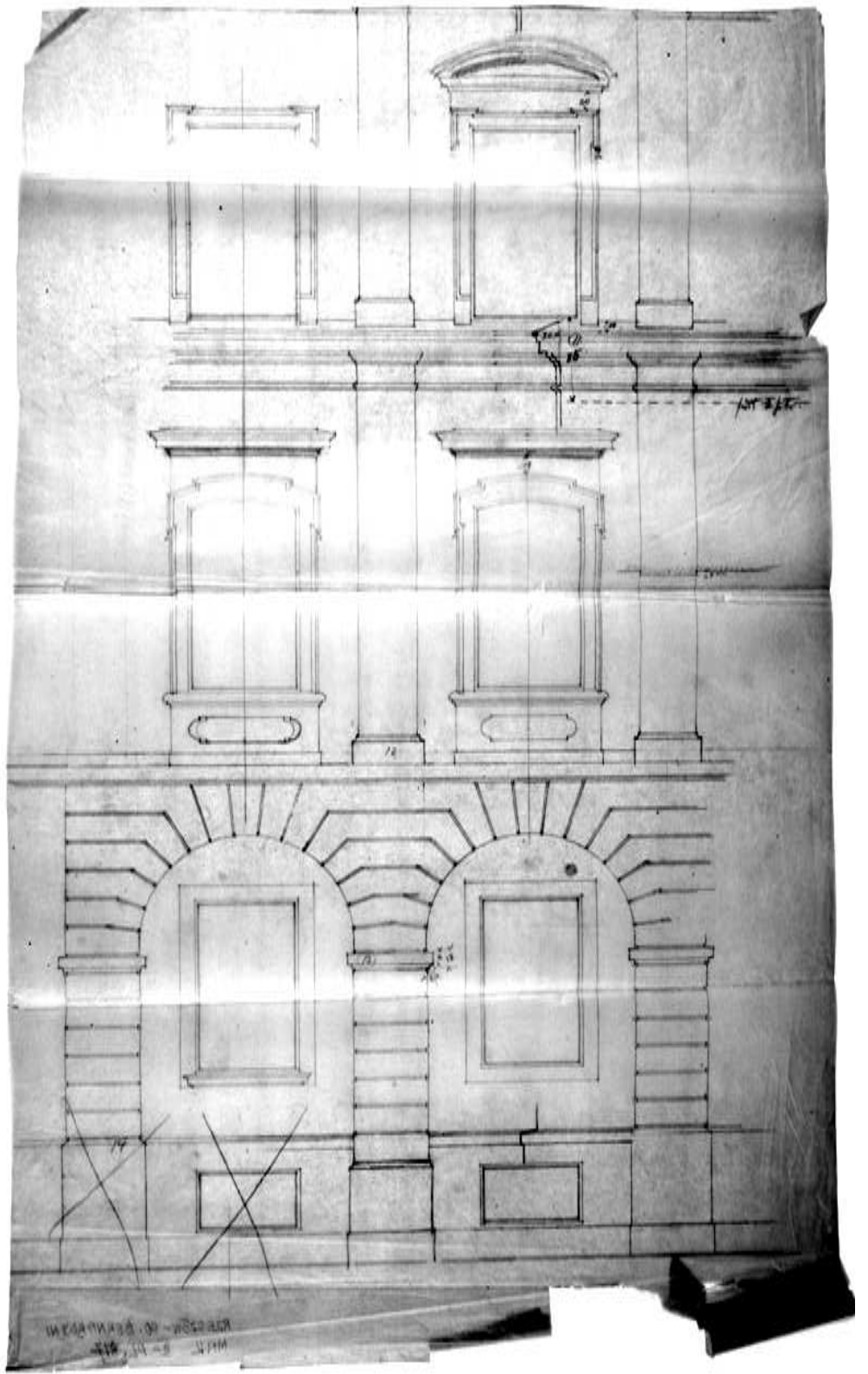

Rys. 2. Fasada frontowa, Muzeum Narodowe w Krakowie ${ }^{30}$

Fig. 2. The front facade, National Museum in Krakow

\footnotetext{
${ }^{30}$ Zygmunt Hendel, Rzeszów - Kościół przy klasztorze OO. Bernardynów - Fasada frontowa Budynek o trzech kondygnacjach (parter, pierwsze i drugie piętro, podpiwniczony), 95 x $41.6 \mathrm{~cm}$, tusz, płótno, Zbiory Muzeum Narodowego w Krakowie, nr inw. MNK III-PL-817.
} 
Na przestrzeni lat 2004-2006 prowadzono prace konserwatorskie osuszające mury fundamentowe, cokół kościoła i klasztoru, a także prace remontowo konserwatorskie murów zewnętrznych i wewnętrznych klasztoru, które kontynuowano także później.

W październiku 2009 roku - dokonano uzgodnień dotyczących możliwości rozbudowy $\mathrm{i}$ adaptacji poddasza klasztornego na cele mieszkalne wraz $\mathrm{z}$ budową ogrodów nad nieistniejącym jeszcze wówczas parkingiem od strony północnej. Potrzeba powiększenia powierzchni mieszkalnej w budynku klasztornym, pojawiła się jak wiemy już wcześniej, na co odpowiedź stanowiły niezrealizowane projekty Hendla, dotyczące nadbudowy kolejnej kondygnacji. Współczesna rozbudowa części mieszkalnej, ograniczona do adaptacji poddasza, które doświetlono lukarnami, ma wybitnie funkcjonalny charakter.

Przebadane projekty znanego architekta krakowskiego Z. Hendla pozwoliły przedstawić jego bogaty warsztat artystyczny. Kreślił rozwiązania architektoniczne bryły i detalu, wystroju wnętrza w każdej skali. Proponował projekty malarskie, rzeźbę i snycerkę. Operował przestrzenią i światłem, posiadał umiejętności wczuwania się $\mathrm{w}$ atmosferę miejsca. Poznawał idee minionych styli i projektował kontynuację odczytanych wartości. Te talenty architekta wpisały twórcę do kart historii architektury. Niemniej należy zauważyć, że propozycje projektowe Z. Hendla nie omijały trendów epoki w której przyszło mu żyć i tworzyć. Projekty elewacji oraz ołtarzy zawierają pierwiastki kierunków charakterystycznych dla przełomu XIX i XX wieku. Zważywszy, jednak kwestię rozwoju konserwatorstwa, to w sposób znaczący, zaświadczają o bardzo rozsądnym i pieczołowitym traktowaniu pamiątek historycznych ze strony wybitnego architekta.

\section{Literatura}

[1] Bogdalski Cz.: Pamiętnik kościoła i klasztoru OO. Bernardynów w Leżajsku, Kraków 1929.

[2] Fischinger A., Krukowski P.: Kościół Bernardynów w Rzeszowie, [w:] Studia renesansowe, t. 3, 1963.

[3] Gosztyła M., Jagieła B.: Reprezentatywne zabytki kultury materialnej Podkarpacia, Jarosław 2004.

[4] Hendel Z., Kopera F.: Kościół św. Idziego, „Biblioteka Krakowska”, Kraków 1905, 29.

[5] Hendel Z., Kopera F.: Resztki murów romańskich w kościele św. Jana w Krakowie, „Rocznik Krakowski”, 1907, T. 9.

[6] Kronika Klasztoru OO. Bernardynów, 1862 r.

[7] Kurowska E., Tokarski W.P. OFM: Bazylika Ojców Bernardynów w Rzeszowie. Przewodnik, Rzeszów 2009.

[8] Laskowski A.: Pałac Klobassy w Skołyszynie - niespełniony sen naftowego magnata, [w:] Dwór polski. Zjawisko historyczne i kulturowe, Warszawa 2000. 
[9] Łuszczkiewicz W.: Klasztor leżajski i jego dzieła sztuki. Wrażenia z podróży, Kraków 1895.

[10] Malczewski J.: Dzieje Rzeszowa do 1914 roku, Rzeszów 1985.

[11] Pierwsze Sprawozdanie CK Szkoły Przemysłowej we Lwowie za rok szkolny 1892/93 (z rysunkami gmachu szkolnego), Lwów 1893.

[12] Stępień P. M.: Hendel Zygmunt, [w:] Polski słownik biograficzny konserwatorów zabytków, red. Henryk Kondziela, Hanna Krzyżanowska, z. 2, Poznań, Wydaw. Poznańskie 2006.

[13] Wojewódzki Urząd Ochrony Zabytków w Rzeszowie: Karta Ewidencyjna Zabytków Architektury i Budownictwa, Kościół OO. Bernardynów w Rzeszowie, opr. J. Malczewski, 10.01.93, zał. nr 1.

[14] Zbiory Wojewódzkiego Urzędu Ochrony Zabytków w Rzeszowie: Dokumentacja Konserwatorska, Rzeszów - ołtarz główny kościoła OO. Bernardynów w Rzeszowie, opr. S. Juszczak, Rzeszów 1996.

[15] Zygmunt Hendel, [w:] Polski Słownik Biograficzny konserwatorów zabytków, red. Kondziela H., Krzyżanowska H., Poznań 2006.

\section{THE CONCEPTION OF RESTORATION OF GROUP BERNARDINE MONASTERY IN RZESZOW BY ZYGMUNT HENDEL THROUGH PRIZM OF SAVED PROJECT DOCUMENTATION}

\section{S u m m a r y}

The aim of the article is an attempt of analysing the assumed concepts of restoring the complex of Friars Minors of Observance in Rzeszów by the architect of Cracow - Zygmunt Hendel. The architect of the famous name and achievements could create his own project concepts of the object with valuable cultural influences along with employing the masters of the highest authority. The in-depth characteristics of restoring projects from the first decade of the 19th century was performed on the basis of the project documentation coming from the resources of the National Museum in Cracow. The projects, whose author is one of the most outstanding architects and restorers at the turn of the 19th and 20th centuries allow approximating the assumed methods of restoration within the mentioned period. These projects are so precious that they may provide a new outlook on the changes made in the development of restoration. It allows us to deepen knowledge of both the history of the discussed monument and its history and development of restoring monuments on the area of Galicia in the period of autonomy. The Cracow architect was the author of many projects and he supervised restoration works performed in the monastery in the years 1896-1906. He created the superstructure concept of the object, introduced the proposal of arcaded development in form of shaped rustication strips and elevation voussoirs on the ground floor from the side of the monastery courtyard. He developed the project of irregular elevation configuration by cresting with a triangle pediment and plastic underlining of corner vertical lines while designing the pilasters with rusticated cores. In the years 2004 - 2006, the monastery underwent the works on drying foundation walls, the works of construction and restoration of external and internal walls of the monastery. In the year 2009, the projects of expansion and adaption of the monastery loft to housing functions and garden establishment from the northern side were accepted. The works performed at the beginning of the 21 st century, in its general concept, constitute the return to the undeveloped projects by $\mathrm{Z}$. Hendel. The contemporary development, retaining the form of a roof, focused on extending the functionality of the interior. 
Keywords: architectural monument, church, monastery, architect, renovation of monuments, Galicia autonomy

Przestano do redakcji: 19.12.2014 r.

Przyjęto do druku: 22.06.2015 r.

DOI:10.7862/rb.2015.42 